\title{
COMPETITIVENESS MEASUREMENT IN TERMS OF THE EUROPE 2020 STRATEGY
}

\author{
- Jan Dobrovic, Peter Gallo, Bohuslava Mihalcova, Lenka Stofova, Petra \\ Szaryszova
}

\begin{abstract}
In this paper, the present state of competitiveness along with other economic issues in a number of EU countries are investigated, with emphasis placed on the economy of Slovakia. Heterogeneous results were produced in terms of the full integration of these economies into the framework of competitiveness stated in the Europe 2020 strategy. In particular, factors were identified which are the results of rating agencies focusing on indicators based on the position of countries in international markets as well as WEF results, which devote more attention to the economic development of countries. The research objective of this paper is to analyse the relations that exist between innovation and competitiveness, taking into account the results of performance assessment models within the selected countries as the object of the research. Using these models, the present authors evaluate the relationship among composite indicators computed with the help of methodologies in order to confirm the cause-and-effect relations between innovation and competitiveness. The research methodology is based on hypothesis verification focused on level of competitiveness in EU countries and especially in Slovakia.
\end{abstract}

Keywords: Europe 2020 strategy, Competitiveness, Model, Composite indicator, Factor analysis, Cluster analysis

JEL Classification: C12, C38, O31, O52, P51

Received: May, 2018

1st Revision: October, 2018

Accepted: November, 2018

\section{INTRODUCTION}

We begin with the proposition that structural weaknesses of the European economy which surfaced during the 2008 financial crisis, i.e. globalization, competition for natural resources and aging of the population, can be resolved via structural reforms. Although these modifications will take place at the national level, they will build on common successes such as the unified market, joint commercial policies and other EU-level implementations. In order to determine solutions to these problems, in 2010 the European Union and its member states began the implementation of a plan to achieve sustainable development for the coming decade, i.e. the Europe 2020 strategy, which deals with short-term challenges related to the crisis and the need for structural reforms. Officially, the competitiveness of countries and support towards them has been 
one of the priorities of the European Union since 2000 with the goal of turning the European Union as a whole into one of "the most competitive economies and most dynamic economies of the world based on knowledge, [an economy] capable of sustainable development, offering higher quality jobs and higher level of social cohesion" (Tausch, 2010; Balcerzak, 2016, Milovic \& Jocovic, 2017; Gavurova et al., 2017; Bánociová \& Martinková, 2017).

The aim of the Europe 2020 strategy is to achieve growth in the European Union during this decade. This is understood as the combination of intelligent growth (economies based on knowledge and innovations), sustainable growth (high competitiveness and a greener economy, imposing less demand for resources) and growth-supporting integration (economies with a high level of employment and demonstrating social and territorial cohesion). EU representatives have therefore defined five major targets of measuring success of the Europe 2020 strategy i.e. employment, research and development, climatic changes and sustainable resources of energy, education and fighting poverty and social exclusion (European Commission, 2017). Of the conclusions of the European Council for Slovakia, one of the most interesting propositions is the need for improvements as well as making use of new scientific and technical knowledge in practice. Slovakia is perceived as a country with strong potential in science and research, and the implementation of the Lisbon Treaty can help us toward a more effective application of this knowledge in practice.

\section{THEORETICAL BACKGROUND}

Before dealing with the issues related to intelligent growth in the European Union, we must take a closer look at the competitiveness of the individual member countries of the EU by way of identifying the current economic performance and challenges in the zone. The development occurring during the past two decades has been disappointing, as Europe has failed to match the USA in productivity factors, while also displaying slower economic growth during both the period prior to as well as after the economic crisis. Whereas Europe's foreign trade is balanced overall and demonstrates a relatively stable level of exports, factors that represent competitiveness at the global level, this is not the case for many individual EU member countries. As stated by theories on international business by Porter (2007), different countries possess different competitive advantages. If a country is rich in natural resources or capital, it has a comparable or relative advantage over the others.

Economic literature has proposed the use of indices for measuring competitiveness, with most global competitiveness indices are implemented at the national level. Certain indices are, however, also utilized at the regional level, e.g. the European Competitiveness Index, the World Knowledge Competitiveness Index, the United Kingdom Competitiveness Index proposed by Robert Huggins Associates, as well as the Atlas of Regional Competitiveness of Euro chambers (Simionescu, 2016). Numerous complex determinants or indicators of competitiveness have been put into use.

Within the list of national ranking by competitiveness, the Global Competitiveness Index (GCI) has become a widely-used tool. GCI values are obtained by dimensioning the weighted average of various components, each of which reflects one aspect of the complex reality termed as 
competitiveness. The countries in the list are ranked by performance and the values obtained (Suleimenova et al., 2018).

Most authors emphasize the importance of innovation for the development of competitiveness and performance in exporting, as demonstrated with results in various countries and with groups of products (Wierzbicka, 2018; Cheba \& Szopik-Depczyńska, 2017; Zygmunt, 2017; Gatto et al., 2011; Jarreau \& Poncet, 2012; Kaimakoudi et al., 2014; Nachum et al., 2001; Sandu \& Ciocanel, 2014; Silgoner et al., 2015; Tomáš, 2011; Xiong \& Qureshi, 2013; Xu, 2010; Chernova et al., 2017; Ussahawanitchakit, 2017; Kisel’áková et al., 2018; Ivanová \& Čepel, 2018). Further analyses have focused on the importance of research and development and their effect on the competitiveness and performance of exporting (Gittleman \& Wolff, 1995; Lefebvre \& Bourgault, 1998; Di Mauro et al., 2005; Priede \& Pereira, 2013; Sandu \& Ciocanel, 2014; Smith, 2002; Meyer \& Meyer, 2016; Androniceanu, 2017a). Performance and measurement of innovation processes in the business environment is crucial for improving country's competitiveness (Zizlavsky, 2016).

Smith (2002) has emphasized that public policies in the field of science, technology and innovations have attracted greater attention with his statement maintaining that the industry of knowledge-based branches represent the core of growth, and that we are entering a completely new "knowledge-based society," hence the inclusion of criteria regarding the ongoing development of the knowledge-based economy in the Europe 2020 strategy.

Rodriguez-Pose \& Crescenzi (2008) emphasize the inevitability of investments into research and development along with the results, i.e. effects on patents and the overall share of the high-tech economy. In this field, numerous research studies have been conducted proving the correctness of this statement. Stronger patent rights can be related to the higher rate of growth in patentbased branches of industry, the influence of which is higher in countries with higher incomes (Hu \& Png, 2009, 2013). In a group of 58 countries, Hasan \& Tucci (2010) determined that in the period from 1980-2003 economic growth increased due to expenditures on research and developments and patents. Many other authors have also investigated the importance of patents for economic development (Chu et al., 2012; Gould \& Gruben 1996; Iwaisako \& Futagami 2013; Zeira, 2011; Shpak et al., 2017; Androniceanu, 2017b). Networking theory is a suitable tool for the strategic management of higher education institutions in the "knowledge-based society" (Nugaras \& Ginevičius, 2015).

\section{RESEARCH OBJECTIVE AND METHODOLOGY}

Our research hypotheses have been defined in the context of the main condition for competitiveness in the market environment, i.e. the ability to endure in the international environment and ensure the higher living standards for the population. The main research hypothesis was defined as follows: Countries with a higher rate of efficiency possess better conditions for achieving a higher level of competitiveness.

From this hypothesis two secondary research hypotheses were identified:

1. The European Union is currently capable of competing with the leading world economies. 
2. The Slovak Republic is currently capable of competing within the European Union.

Thus, competitiveness remains at the forefront of interest for every state and integrational group, and competitiveness studies are increasing well ahead of the dimensions of the European process of integration. Not only the EU member countries, but the European Union as a whole faces the challenge of becoming more competitive to operate more successfully in the globalized economy.

The study research sample of EU countries was analysed and assessed within the framework of the development within the respective countries on the basis of selected indicators of competitiveness. The indicators were analysed for all EU member countries and over the entire research period. Finally, the indicators are compared to one another as well as to the standard indicators of economic performances, which includes GDP in parity with purchasing power per capita. This approach allowed us to occasionally discard certain indicators from the analysis which would provide results substantially differing from the rest of them. On the basis of the computed values of these complex indicators for the entire period under research, the evaluation covers the development of competitiveness of the EU countries, while identifying cases of increased competitiveness within the EU over the selected period of time. Similarly, this allows for comparisons to demonstrate how measurement of the competitiveness of EU countries varies when different methodological approaches and indicators are applied.

The selected indicators form the basis for the evaluation and comparison of the competitiveness of the EU states for the period of 2006-2016. The period was selected with regard to the data availability. For the year 2017, the data were not accessible in time for processing or did not exist for some of the countries. The data were obtained from standard databases, with major sources primarily those from Eurostat, AMEC and the World Bank.

Further concrete indicators have also been acquired from the databases of the Economic Forum, World Governance Indicators and Index of Economic Freedom. When necessary, missing data have been gradually compiled from the national databases of particular statistical offices or central banks.

The research methodology is based on the original work of the authors Fagerberg, Srholec, Knell (2004, 2005 and 2007) and Aiginger et al. (2013) which has been modified both in terms of data availability and in terms of the monitored group of countries. According to these authors, it is necessary to distinguish between technological ( $T$ ) and capacity $(C)$ competitiveness. While technological competitiveness is linked to innovation ability and reflects the country's ability to succeed in markets with new goods or services, capacity competitiveness assesses the country's ability to use new innovations economically. They divide the variables that determine the level of technological competitiveness into three dimensions: S \& T inputs, S \& T outputs, and information and telecommunication technologies (ICT infrastructure). Gross domestic expenditure on research and development (GERD) is an indicator to approximate resources for the development of new goods and services. On the opposite side of the innovation process, certain indicators measure outputs of this creative activity, in which two indicators (number of patents and number of articles in scientific and technical journals) are represented. To assess the quality of ICT infrastructure, the authors chose the number of personal computers and fixed telephone 
lines per capita. The selection of indicators to describe the level of capacity competitiveness was based on the work of Abramovitz $(1989,1994)$, who emphasized the importance of three groups of factors: technical / organizational competence (respectively level of education), availability / quality of financial institutions (markets) and quality / efficiency of government. Subsequently, a set of indicators was selected which in the authors' view satisfactorily represent the three groups of factors. For the approximation of the level of education, an indicator of the number of enrolled students in secondary and tertiary grades along with an indicator of the average length of school education were selected. The quality of financial markets was assessed using the CIM (Contract Intensive Money) indicator, domestic private sector loans and the inflation indicator. The authors found that the most problematic indicator is the measurement of government quality, especially when it became necessary to work with a time series. These quality assessments respective to the effectiveness of government is usually based on the views of the experts, which negatively affects time comparability.

Conducting this research involves defining indicators which are related and compared within the member states of the union, while a referential framework was established in the form of the EU27 average. By way of a cross-sectional analysis of the indicators of competitiveness, we have assessed the rate of efficiency for the individual member countries against the performance level of this group. Based on a cluster analysis, it is possible to classify the EU countries from an external point of view into heterogeneous entities, and from an internal point of view into homogenous groups demonstrating similar characteristics and problems affecting the competitiveness of these countries. Identifying the indicators helped form a database of relevant statistical indicators reflecting the economic, social and environmental performance of the area and that which can be regarded as a source of competitive potential for selected countries of the EU.

Due to the great number of indicators representing the basic variables for the analysis of competitiveness and their mutual correlation, the method of factor analysis was applied, an approach that reduced the original number of input variables that became part of the major factors of competitiveness for them to be specified in greater detail. As a follow-up to the factor analysis, the segmentation of the reduced indicators of national competitiveness was carried out, in the basis of which clusters of countries with similar traits were identified. The value of the factor score was used to establish the limits of the minimal value of the dynamic development for the respective factors in the clusters (Sopoligová \& Pavelková, 2017).

In the long run, an evaluation of competitiveness requires considering not only economic but also the social and environmental factors which are not only intensive but primarily extensive by their nature. Consequently, the competitiveness of individual countries is affected by both quantitative and qualitative factors, which can turn internal and external by nature, and these factors acting jointly may have a more intensive impact on the resulting competitiveness of the EU member states.

As for the countries themselves, the potential for development for each was assessed on the basis of a comparative analysis of the rates of efficiency obtained in the light of the inputs used, outputs produced, along with the structures of key quantitative and qualitative factors of the dynamics of territorial development. In compliance with the suggested methodology, the common factors were identified for which the "factor load" (weight) will be determined representing the 
measure of dependence between the original indicator and its factor. The rotation of factors and the estimation of the factor score expressing the extent to which particular factors are acting in the respective countries were carried out subsequently. These calculations form the basis of the interpretation of the extracted factors and their territorial differentiation.

\section{RESULTS AND DISCUSSION}

In this part, approaches to the competitiveness of countries are presented by which to interpret particular groups of priorities specified in the Europe 2020 strategy. Then a new indicator of competitiveness was indentified in which both technology the capacity aspects of competitiveness are interconnected, thus enabling the evaluation of development in the field of the first priority of the Europe 2020 strategy, i.e. intelligent growth. This new comprehensive indicator of technology and capacity-based competitiveness will be designated in the rest of this paper as the indicator of qualitative competitiveness. The unique approach of Karol Aiginger et al. (2013) to competitiveness of countries which focuses on outputs instead of on inputs was implemented, with the resulting indicator termed the indicator of efficient competitiveness. Unlike traditional price-cost indicators of the competitiveness of countries, we have also submitted derived indicators comprising extra comparative elements expressing how the given country is competitive in comparison with the rest of the countries in the given group (in this case within the EU).

\subsection{Quality-based competitiveness}

The last step involves interconnecting both aspects of competitiveness analysed earlier, whereby we obtained an indicator that evaluates both the ability to innovate and to make use of the available technologies. Thus, the new indicator of quality-based competitiveness expresses the extent of intelligent growth taking place in the EU countries, i.e. the extent to which their economy is based on knowledge and innovations.

Consequently, we have to interconnect all the indicators of technology and capacity-based competitiveness into a single entity. For this purpose, it is necessary to perform analyses of the main components and factors as well as to establish new weights to the individual variables to this widened set of indicators. Again, the first step involves the analysis of the main components to help determine how many components or factors will be dealt with in the follow-up factor analysis. When choosing the number of relevant factors, we again will follow the same rules (Tab. 1).

Tab. 1 - Values of the correlation matrix for the indictor of quality-based competitiveness. Source: authors' processing using Eurostat, ISI, the World Bank, AMECO, UNESCO, Worldwide Governance Indicators, and the Index of Economic Freedom (2016)

\begin{tabular}{|l|l|l|l|l|}
\hline \multirow{2}{*}{$\begin{array}{l}\text { Type of com- } \\
\text { petitiveness }\end{array}$} & \multicolumn{2}{|l|}{ Serial number of the prop. no. } & Proper number & \% of total variance \\
\hline \multirow{3}{*}{ T } & 1. & GERD & 8.4485 & 52.87848 \\
\cline { 2 - 5 } & 2. & Patents & 2.1468 & 13.43665 \\
\cline { 2 - 5 } & 3. & Articles & 1.2223 & 7.650277 \\
\hline
\end{tabular}




\begin{tabular}{|l|l|l|l|l|}
\hline \multirow{4}{*}{$\mathrm{T}$} & 4. & Internet & 1.0386 & 6.500513 \\
\cline { 2 - 5 } & 5. & Telephones & 0.9146 & 5.724407 \\
\hline \multirow{4}{*}{ C } & 6. & Tert. education & 0.6265 & 3.921213 \\
\cline { 2 - 5 } & 7. & Sec. education & 0.3894 & 2.437223 \\
\cline { 2 - 5 } & 8. & Length of study & 0.3522 & 2.204391 \\
\cline { 2 - 5 } & 9. & Loans & 0.2160 & 1.351926 \\
\cline { 2 - 5 } & 10. & Int. rate & 0.1734 & 1.085297 \\
\cline { 2 - 5 } & 11. & Saving & 0.1404 & 0.878752 \\
\cline { 2 - 5 } & 12. & Government regulation & 0.0991 & 0.620259 \\
\cline { 2 - 5 } & 13. & Pol. stability & 0.0896 & 0.560799 \\
\cline { 2 - 5 } & 14. & Propr. rights & 0.0700 & 0.438124 \\
\cline { 2 - 5 } & 15. & Corruption & 0.0498 & 0.311694 \\
\hline
\end{tabular}

The proper number of the first factor is 8.4485 and is explaining more than $50 \%$ of the total dispersion, the second factor with proper number 2.1468 is explaining $13.43665 \%$ of the dispersion. The third and fourth factors will also be involved into the analysis even though they do not meet the requirement of $10 \%$ of the explained dispersion, but their proper numbers are higher than one. We will also take into consideration the fifth factor, the proper number of which as almost one (0.91). Thus, the factor analysis will involve 5 factors with the proper number higher than 0.9 that altogether are explaining $85.3 \%$ of the total dispersion.

Tab. 2 - Factor analysis for the quality-based competitiveness of EU countries. Source: authors' processing using Eurostat, ISI, the World Bank, AMECO, UNESCO, Worldwide Governance Indicators. Index of Economic Freedom (2016)

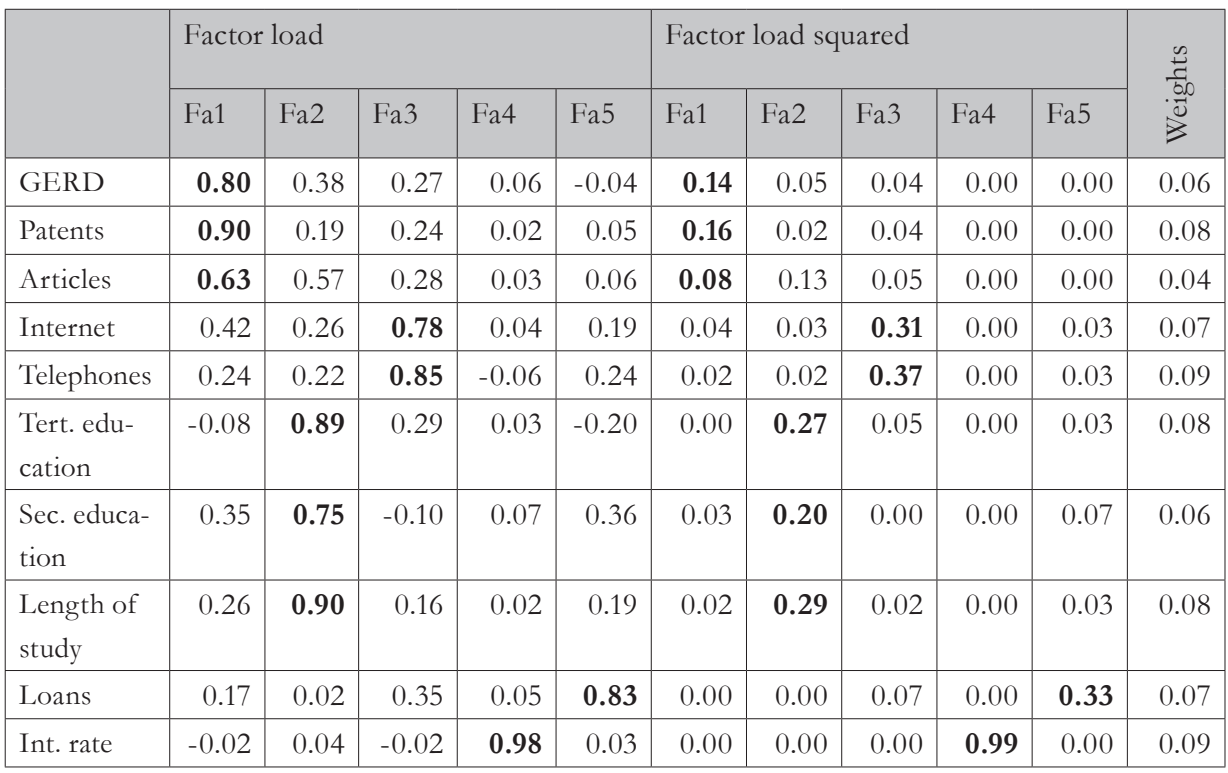




\begin{tabular}{|l|c|c|c|c|c|c|c|c|c|c|c|}
\hline Saving & $\mathbf{0 . 8 3}$ & -0.06 & 0.33 & -0.02 & 0.26 & $\mathbf{0 . 1 4}$ & 0.00 & 0.06 & 0.00 & 0.04 & 0.06 \\
\hline $\begin{array}{l}\text { Govern- } \\
\text { ment } \\
\text { regulation }\end{array}$ & $\mathbf{0 . 7 2}$ & 0.16 & 0.16 & -0.05 & 0.56 & $\mathbf{0 . 1 1}$ & 0.03 & 0.03 & 0.00 & 0.15 & 0.05 \\
\hline $\begin{array}{l}\text { Pol. stabil- } \\
\text { ity }\end{array}$ & $\mathbf{0 . 7 6}$ & -0.02 & -0.10 & -0.10 & 0.07 & $\mathbf{0 . 1 2}$ & 0.00 & 0.00 & 0.02 & 0.00 & 0.06 \\
\hline $\begin{array}{l}\text { Propr. } \\
\text { rights }\end{array}$ & $\mathbf{0 . 7 1}$ & 0.12 & 0.05 & -0.04 & 0.64 & $\mathbf{0 . 1 1}$ & 0.00 & 0.00 & 0.00 & 0.20 & 0.05 \\
\hline Corruption & $\mathbf{0 . 7 8}$ & 0.24 & 0.22 & 0.04 & 0.42 & $\mathbf{0 . 1 3}$ & 0.03 & 0.03 & 0.00 & 0.09 & 0.06 \\
\hline $\begin{array}{l}\text { Expl. vari- } \\
\text { ance }\end{array}$ & 5.14 & 2.90 & 1.95 & 1.03 & 2.09 & & & & & & \\
\hline $\begin{array}{l}\text { Expl. /To- } \\
\text { tal variance }\end{array}$ & 0.42 & 0.23 & 0.18 & 0.11 & 0.19 & & & & & & \\
\hline
\end{tabular}

Factor loads (Tab. 2) larger than 0.6 are written in boldface letters and determine which factor the given variable belongs to (we are selecting the factor at which the given variable has the highest value of factor load). For example, the variable of gross expenditures for research and development (GERD) has the highest factor load at the first factor $(0.78$ or 0.13 after raising it to the second power and adjusting it into a unit sum), and, consequently, it forms part of the first factor. On the contrary, the variable of the number of internet users (internet) belongs to the third factor, because here the factor load is the highest $(0.78$ or 0.31 after raising it to the second power and adjusting it into a unit sum).

The first factor comprises variables such as gross expenditures on research and development, number of articles and patents, gross savings, government regulation, political stability, proprietary rights and corruption. The second factor is made up of the indicator of secondary and tertiary education plus length of education. The third factor comprises the numbers of internet users and of telephones, while the interest rate is indicated by the fourth factor and loans of the private sector by the fifth. Important information for the individual factors can be found in the last line of the table, where the given number expresses the weights of the individual factors' shares on the total indicator. These weights are subsequently divided among the individual variables making up the given factor. For example, factor 1's share on the composite indicator takes the weight of $39 \%$, whereas in the last column of the table GERD's share is weighted to 0.07 , patents 0.08 , articles 0.04 , savings 0.06 , government regulations 0.05 , political stability 0.06 , proprietary rights 0.05 and corruption 0.06 .

\subsection{Efficient competitiveness}

In these times of globalization, businesses face rapid changes both in customer needs as well as in the nature of the markets. In order for companies to gain a competitive edge and improve their performance, they have to develop new products and strategies to attract new customers and satisfy existing ones (Ungerman et al., 2018)

The final chosen approach to the competitiveness of countries is an attempt to incorporate the priority of sustainable development along the inclusive growth described in the Europe 2020 
strategy. Unlike the previous complex indicators, efficient competitiveness is exclusively oriented on the evaluation of outcomes, i.e. the effects.

Based on the results of Aigingera et al. (2013) and considering data availability for the selected period, four indicators have been chosen, the first of which is the proportion of persons threatened by poverty in the population as a whole along with those older than 65 , considering social transfers in both cases. The two indicators to follow are concerned with the rate of unemployment, namely that of long-term unemployment and juvenile unemployment between 15-29 years of age. The last pillar was marked by Aiginger et al. (2013) as the environmental pillar, which expresses the results in this field. Making use of the results of Aiginger et al. (2013), two indicators were chosen from this field: productivity of sources and share of energy from renewable sources.

In view of the follow-up construction of the composite indicator, when the normed variables are weighted by the weights derived from this factor along with the need to interpret the resulting indicator of efficient competitiveness, it is inevitable that all variables act upon the composite indicator in the same direction. For all indicators of the income and environmental pillar, it holds that the higher values indicate economies with higher a level of competitiveness. However, the opposite is true for the indicators of the social pillar, where the relation between this indicator and country competitiveness is indirectly proportional. For this reason, we will further work with the inverse values of these indicators (Tab. 3).

Tab. 3 - Values of the correlation matrix for the indicator of efficient competitiveness. Source: authors' processing using Eurostat, AMECO, World Bank (2016)

\begin{tabular}{|l|l|l|l|}
\hline \multicolumn{2}{|l|}{ Ser. number of the prop. no. } & Proper number & \% of total variance \\
\hline 1. & Disposable Income (DI) & 4.5133 & 45.13526 \\
\hline 2. & National Income (NI) & 1.8065 & 18.0659 \\
\hline 3. & Household Expenditures (HE) & 1.2097 & 12.0976 \\
\hline 4. & Productivity of sources & 1.0337 & 10.33752 \\
\hline 5. & Renewable sources & 0.5909 & 5.909295 \\
\hline 6. & Poverty & 0.3285 & 3.285164 \\
\hline 7. & Poverty (older than 65) & 0.3090 & 3.090155 \\
\hline 8. & Long-term unemployment & 0.1624 & 1.624081 \\
\hline 9. & Juvenile unemployment & 0.0355 & 0.355018 \\
\hline
\end{tabular}

Now, we have a set of variables which together make up the composite indicator of efficient competitiveness. It is important to establish the weights of the variables respectively (Tab. 4). To this end, the analysis of the main components and factor analysis were used again. The analysis of the main components helps us find out into how many groups (factors) the variable will be classified within the framework of the factor analysis. 
Tab. 4 - Factor analysis for efficient competitiveness of EU countries. Source: authors' processing by Eurostat, AMECO, SPL, the World Bank (2017)

\begin{tabular}{|c|c|c|c|c|c|c|c|c|c|}
\hline & \multicolumn{4}{|c|}{ Factor load } & \multicolumn{4}{|c|}{ Squared factor load } & \multirow{2}{*}{ 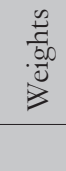 } \\
\hline & $\mathrm{Fa} 1$ & $\mathrm{Fa} 2$ & $\mathrm{Fa} 3$ & $\mathrm{Fa} 4$ & $\mathrm{Fa} 1$ & $\mathrm{Fa} 2$ & $\mathrm{Fa} 3$ & $\mathrm{Fa} 4$ & \\
\hline $\begin{array}{l}\text { Disposable Income } \\
\text { (DI) }\end{array}$ & 0.97 & 0.04 & 0.16 & 0.05 & 0.24 & 0.00 & 0.02 & 0.00 & 0.12 \\
\hline $\begin{array}{l}\text { National Income } \\
\text { (NI) }\end{array}$ & 0.94 & 0.09 & 0.27 & 0.13 & 0.23 & 0.00 & 0.04 & 0.02 & 0.12 \\
\hline $\begin{array}{l}\text { Household Expen- } \\
\text { ditures (HE) }\end{array}$ & 0.96 & 0.03 & 0.24 & 0.13 & 0.24 & 0.00 & 0.04 & 0.02 & 0.11 \\
\hline $\begin{array}{l}\text { Productivity of } \\
\text { sources }\end{array}$ & 0.90 & 0.16 & 0.08 & -0.22 & 0.21 & 0.02 & 0.00 & 0.05 & 0.10 \\
\hline Renewable sources & 0.09 & -0.08 & -0.03 & 0.96 & 0.00 & 0.00 & 0.00 & 0.80 & 0.13 \\
\hline Poverty & 0.22 & 0.83 & 0.31 & 0.07 & 0.02 & 0.40 & 0.06 & 0.00 & 0.11 \\
\hline $\begin{array}{l}\text { Poverty (older than } \\
65 \text { ) }\end{array}$ & 0.15 & 0.81 & -0.15 & -0.31 & 0.02 & 0.38 & 0.02 & 0.08 & 0.10 \\
\hline $\begin{array}{l}\text { Long-term unem- } \\
\text { ployment }\end{array}$ & 0.34 & -0.05 & 0.85 & 0.17 & 0.04 & 0.00 & 0.42 & 0.02 & 0.10 \\
\hline $\begin{array}{l}\text { Juvenile unemploy- } \\
\text { ment }\end{array}$ & 0.22 & 0.14 & 0.88 & -0.19 & 0.02 & 0.02 & 0.45 & 0.03 & 0.11 \\
\hline Explained variance & 3.95 & 1.76 & 1.73 & 1.14 & & & & & \\
\hline $\begin{array}{l}\text { Expl. /Total vari- } \\
\text { ance }\end{array}$ & 0.45 & 0.22 & 0.21 & 0.12 & & & & & \\
\hline
\end{tabular}

On the basis of the results obtained, we can state that for the DI the highest load is 0.95 . Consequently, net disposable income belongs with the first factor. Along with this, the net NI and HE for consumption and productivity of sources can be placed as well. The total of these 4 variables represent a $45 \%$ share on the aggregate indicator. The second factor is made up of the indicators of poverty share of total population and of population over 65 years of age. Both indicators form a share of $22 \%$ of the total indicator. Long-term unemployment and juvenile unemployment form part of the third factor and in the indicator of efficient competitiveness have the weight of $21 \%$. Renewable sources have the highest factor load, which takes a $12 \%$ share of the aggregate indicator. The final weights of the individual indicators of efficient competitiveness range from 0.10 to 0.13 .

\subsection{Comparation and verification of results}

Taking a look at the results of composite indicator, we can see certain similarities in a listing of the EU countries ordered by their competitiveness. As has already been mentioned, it is of no significance to compare traditional indicators of competitiveness with composite indicators, as the latter comprise substantially more information. Consequently, we focus on the similarity of 
results between the Global Competitiveness Index (GCI) and the indicators of technology and capacity-based competitiveness.

The purpose of evaluating the extent of similarity among the indicators is well-served by a correlation matrix (Tab. 5). Apart from mutual correlations of the 5 composite indicators of competitiveness, the calculations also involved determining the correlation coefficients of the indicators of competitiveness individually as well as the GDP in parity with the purchasing power per capita. As mentioned above, there is a close relationship between the level of GDP and the competitiveness of a country; thus a well-structured composite indicator of competitiveness should present a high degree of correlation with GDP per capita.

Tab. 5 - Correlation matrix of the GDP and tie indicators of competitiveness. Source: authors' processing

\begin{tabular}{|l|r|r|r|r|r|l|}
\hline GCI & \multicolumn{1}{l|}{ TC } & \multicolumn{1}{l|}{ CC } & \multicolumn{1}{l|}{ QC } & \multicolumn{1}{l|}{ EC } & \multicolumn{1}{l|}{ GDP } & \\
\hline 1 & 0.80 & 0.81 & 0.84 & 0.77 & 0.58 & GCI \\
\hline & 1 & 0.80 & 0.94 & 0.85 & 0.69 & TC \\
\hline & & 1 & 0.97 & 0.76 & 0.74 & CC \\
\hline & & & 1 & 0.83 & 0.76 & QC \\
\hline & & & & 1 & 0.87 & EC \\
\hline & & & & & 1 & GDP \\
\hline
\end{tabular}

Note: GCI - Global Competitiveness Index. TC - Technology-based competitiveness. CC - Capacity-based competitiveness. QC - Quality-based competitiveness. EC - Efficient competitiveness. GDP - Gross Domestic Product.

The lowest correlation coefficient has been found between the indicator of capacity-basis and that of efficient competitiveness. However, even this value shows a strong and positive correlation of the results of the two indicators. Equally, a strong and positive correlation holds for all of the remaining pairs of indicators of competitiveness. The most similar results were provided by the indicators of quality-based and technology-based competitiveness $(R=0.94)$, or by capacity-based competitiveness $(R=0.97)$. However, these correlation coefficients are understandably affected by the fact that the indicator of quality-based competitiveness is made up of indicators constituting the indicators of technology and capacity-based competitiveness and there is no point in taking these results into account.

In the last column of the correlation matrix, there are correlation coefficients between GDP per capita and the respective indicators of competitiveness. The lowest level of correlation was found between the GDP and the GCI ( $=0.58)$. The remaining indicators structured and calculated in the previous sub-chapter show a strong and positive correlation with GDP per capita ( $\mathrm{R} \geq$ 0.69). The highest coefficient of correlation $(R=0.87)$ was found as expected, for the relation between GDP per capita and the indicator of efficient competitiveness. Nevertheless, the paired correlation coefficients for the composite indicators of competitiveness turned out to be high. The results of these indicators vary as a matter of course. 


\subsection{A multidimensional (multi-criterial) approach to the evaluation of competitiveness of EU countries}

Important results have been obtained via analysing the development of four composite indicators calculated for the EU countries. A clear-cut rising trend has been confirmed by the indicator of technology-based competitiveness. The capability for innovation is improving in all EU countries. As for the composite indicator of capacity-based competitiveness, it has been proven that except for Belgium, Great Britain and Germany the level of competitiveness in all EU countries in 2016 was high. In Belgium, there was a steep fall in capacity-based competitiveness caused by the standardization of the number of students at secondary-level education. In Germany, it was due to a long-lasting drop in loans to private sectors and poor political stability, whereas in Great Britain it was the result of dropping gross savings and a lower quality of governance. After merging the indicator of technology and capacity-driven indicators into a single indicator of the quality of competitiveness, the rising trend of competitiveness of EU countries has been proven again. EU countries are improving their ability to innovate and at the same time, they are capable of finding the never ending opportunities and advantages offered by new technologies. In 2016, less efficient competitiveness was displayed in Bulgaria and Cyprus at the very beginning. In Bulgaria, there was no substantial progress if the partial variables are taken both individually and otherwise. A rise in poverty and unemployment was reflected in the composite indicator and thus Bulgaria was shown as the country with the lowest level of competitiveness in the European Union in 2016.

Another partial goal of the research was to compare the results obtained as various approaches to the evaluation of competitiveness in the EU countries are implemented. Even the approach used as last in the evaluation of competitiveness of EU countries indicates growing competition in the member countries. A multidimensional evaluation was undertaken which represents a complex of quantifiable and qualitative indicators (Fig. 1).

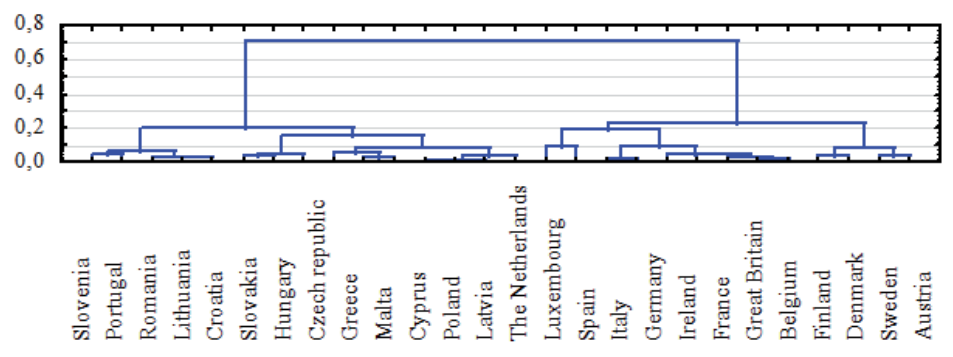

Fig.1 - Complete results of the cluster analysis of identified composite indicators of competitiveness (2017). Source: authors' processing

On principle, it can be stated that the highest level of competitiveness demonstrated by the economies within the EU are represented by countries in the north of Europe and by the Netherlands, Germany, Austria, Luxembourg and Great Britain - countries which by all indicators belong to the top 10 of the European Union based on the indicators of capacity-based com- 
petitiveness and quality of competitiveness. Slovakia has already twice been rated among the 10 countries with the lowest competitiveness within the European Union. It is in the already mentioned capacity-based competitiveness that the SR is apparently lagging behind, most apparently in the quality of financial markets, education and the quality of governance. Slovakia is gradually reducing its lag behind the most successful countries of the EU.

\section{CONCLUSION}

As there is no general agreement regarding the measurement of the competitiveness of an economy, the present authors present various approaches as well as offer explanations regarding appropriate ways of measuring competitiveness. Many of the frequently used approaches to the evaluation of competitiveness of countries have become unsuitable. These imprecise methods focus on the price-cost-based competitive advantage, which in view of the developed EU countries cannot be sustained in the long run due to the large share of soft data on complex competitiveness indicators, i.e. those of world institutions such as the World Economic Forum or the International Institute for the Development of Management.

The indicator of efficiency of competitiveness bears witness to the fulfilment of those goals of the sustainable growth and development which are primarily focused on environmental and social indicators. Apart from this, the selected approaches must be applicable to the countries of the European Union and must enable the calculation of the relevant complex indicators with the aim of fulfilling the initial goals of our research. We have been searching for answers to the research question of whether there is a rise in the competitiveness of the EU countries, with each issue taken one by one. Competitiveness of EU countries was here initially expressed making use of the indicators presented in professional references along with currently available databases.

The member states of European Union continue to improve their capacity to innovate the implementation of new technologies. The final approach used here to assess the competitiveness of EU countries points to the growth of competitiveness of the member states. Based on this result, we can judge that the first of two secondary research hypotheses has been confirmed. From the above it follows that the competitiveness of the EU countries is gradually increasing. Moreover, the success of the country in the area of one of the sub-indicators is often offset by a weak position in another indicator. All this is reflected in the low values of the composite indicator of effective competitiveness in the countries of the European Union. The potential for improving the competitiveness of the individual countries of the European Union as well as the EU as a whole can be found only among the sub-indicators of the composite indicator. Otherwise, these factors may have a negative impact on the competitiveness of the European Union as a whole in the future.

As can be seen from analyses of Slovakia's preparedness for intelligent growth, the formation of its own executive research, technological and innovation base has been neglected. Successfully overcoming this lag behind the more advanced economies is determined by the quality of human capital. However, the weakest assessment, i.e. of the quality of Slovakia's education system among economies EU 28, suggests that even in this direction Slovakia is not well-prepared for intelligent growth. Emerging economies often succumb to a vicious circle revolving around 
a low level of human capital, low technological advancement, and weak innovation potential, which is a situation that Slovakia is currently dealing with. This is evidenced by the weak interest of foreign investors in research and innovation of domestic origin along with a lack of domestic highly qualified specialists as well as in the overall demand for intangible activities. Efforts to improve education, support for R \& D and innovation, especially in the domestic business sector, and a general focus on qualitative economic factors has also dampened the enthusiasm from previously promising economic results. Our findings confirm that Slovakia's competitiveness needs to be increased, thus we must reject our second research hypotheses.

\section{Acknowledgment}

The paper is the outcome of VEGA Project No. 1/0255/2016 "Research on the possibility of optimization of process-oriented models of the financial administration management with a focus on transfer pricing and tax harmonization in the terms of EU." and of the Project of Young Scientists, Young Teachers and PhD students No. I-18-109-00.

\section{References}

1. Androniceanu, A. (2017a). The three-dimensional approach of Total Quality Management, an essential strategic option for business excellence. Amfiteatru Economic, 19 (44), 61-78.

2. Androniceanu, A. (2017b). Hospital management based on the relationship between doctors and patients. Administratie si Management Public, 29, 41-53.

3. Balcerzak, A. P. (2016). Multiple-criteria Evaluation of Quality of Human Capital in the European Union Countries. Economics and Sociology, 9 (2), 11-26.

4. Bánociová, A., Martinková, S. (2017). Active Labour Market Policies of Selected European Countries and Their Competitiveness. Journal of Competitiveness, 9 (3), pp. 5-21. https://doi. org/10.7441/joc.2017.03.01

5. Cheba, K., \& Szopik-Depczyńska, K. (2017). Multidimensional comparative analysis of the competitive capacity of the European Union countries and geographical regions. Oeconomia Copernicana, 8 (4), 487-504. https://doi.org/10.24136/oc.v8i4.30.

6. Chernova V. Y., Zobov A. M., Starostin V. S., \& Butkovskaya G. V. (2017). Sustainable marketing communication strategies of Russian companies under the import substitution policy. Entrepreneurship and Sustainability Issues, 5 (2), 223-230. https://doi.org/10.9770/ jesi.2017.5.2(5)

7. Chu, A. C. Leung, CH. K. Y, \& Tang, E. (2012). Intellectual Property Rights. Technical Progress and the Volatility of Economic Growth. Journal of Macroeconomics, 34, 749-56.

8. David N. (2010). The Lisbon Strategy. Europe 2020 and the Crisis in Between. European social Observatory, (May), 93-113.

9. Gatto, M. D. et al. (2011). The Revealed Competitiveness of U.S. Exports. International Finance Discussion Papers (1026).

10. Gavurova B., Soltes, M., \& Kovac, V. (2017). Application of Cluster Analysis in the Process of Competitiveness Modelling of Slovak Republic Regions. Transformations in Business and Economics, 16(3), 129-148.

11. Gittleman, M., \& Wolff, E. N. (1995). R\&D Activity and Cross-Country Growth Comparisons. Cambridge Journal of Economics, 19 (1), 189-207. 
12. Gould, D. M., \& William C. Gruben. (1996). The Role of Intellectual Property Rights in Economic Growth. Journal of Development Economics, 48 (2), 323-350.

13. Hasan, I., \& Tucci, Ch. L. (2010). The Innovation-Economic Growth Nexus: Global Evidence. Research Policy, 39 (10), 1264-76.

14. Hu, A. G. Z., \& Png. I. P. L. (2009). Patent Rights and Economic Growth: Cross-Country Evidence. Science 1-25.

15. Hu, A. G. Z., \& Png, I. P. L. (2013). Patent Rights and Economic Growth: Evidence from Cross Country Panels of Manufacturing Industries. Oxford Economic Papers, 65 (1), 675-98.

16. Ivanová, E., \& Čepel, M. (2018). The Impact of Innovation Performance on the Competitiveness of the Visegrad 4 Conutries. Journal of Competitiveness, 10 (1), 54-72. https:// doi.org/10.7441/joc.2018.01.04

17. Iwaisako, T., \& Futagami, K. (2013). Patent Protection. Capital Accumulation \& Economic Growth. Economic Theory, 52 (1), 631-68.

18. Jarreau, J., \& Poncet, S. (2012). Export Sophistication and Economic Growth: Evidence from China. Journal of Development Economics, 97 (2), 281-92. Retrieved January 9. 2015 (http://www.sciencedirect.com/science/article/pii/S0304387811000320).

19. Kaimakoudi, E., Polymeros, K., \& Batzios, Ch. (2014). Investigating Export Performance and Competitiveness of Balkan and Eastern European Fisheries Sector. Procedia Economics and Finance, 9, 219-30. Retrieved January 30. 2015 (http://www.sciencedirect.com/science/ article/pii/S2212567114000239).

20. Kiseláková, D., Šofranková, B., Čabinová, V., \& Onuferová, E. (2018). Competitiveness and sustainable growth analysis of the EU countries with the use of Global Indexes methodology. Entrepreneurship and Sustainability Issues, 5 (3), 581-599. https://doi. org/10.9770/jesi.2018.5.3(13)

21. Lefebvre, E., Lefebvre, L. A., \& Bourgault, M. (1998). R\&D-Related Capabilities as Determinants of Export Performance. Small Business Economics, 10, 365-77.

22. Di Mauro. F. et al. (2005). Competitiveness and the Export Performance of the Euro Area. ECB Occasional Paper. Retrieved (http://papers.ssrn.com/sol3/papers.cfm?abstract_ id=752090\nhttp://www.suomenpankki.fi/pdf/118644.pdf).

23. Meyer, N., \& Meyer, D. F. (2016). The relationship between the creation of an enabling environment and economic development: A comparative analysis of management at local government sphere. Polish Journal of Management Studies, 14 (2), 150-160. https://doi. org/10.17512/pjms.2016.14.2.14

24. Milovic, N., \& Jocovic, N. (2017). Impact of Foreign Direct Investment on Competitiveness of Montenegrin Economy. Transformations in Business and Economics, 16 (1), 223-232.

25. Nugaras. J., \& Ginevičius. R. (2015). The strategic assessment of networking of a higher education institution. Economic Research-Ekonomska Istraživanja, 28 (1), 31-44. https//doi.org/ 10.1080/1331677X.2014.995963

26. Porter, M. (2007). Competitive Advantage of Nations. Bloomsbury Business Library Management Library 18. Retrieved (http://search.ebscohost.com/login.aspx?direct $=$ true\& $\mathrm{db}=\mathrm{bth} \& \mathrm{AN}=26659561 \&$ lang $=$ es\&site $=$ ehostlive $)$. 
27. Priede, J., \& Pereira, E. T. (2013). Innovation as a Key Factor in the International Competitiveness of the European Union. European Integration Studies, (7), 212-21. http:// dx.doi.org/10.5755/j01.eis.0.7.4228

28. Rodríguez-Pose, A., \& Crescenzi, R. (2008). Research and Development. Spillovers. Innovation Systems. and the Genesis of Regional Growth in Europe. Regional Studies, 42 (1), 51-67. https://doi.org/10.1080/00343400701654186

29. Sandu, S., \& Ciocanel, B. (2014). Impact of R\&D and Innovation on High-Tech Export. Procedia Economics and Finance, 15 (14), 80-90. https://doi.org/10.1016/S2212-5671(14)00450-X

30. Shpak, N., Satalkina, L., Sroka, W., \& Hittmar, S. (2017). The social direction of enterprises' innovation activity. Polish Journal of Management Studies, 16 (1), 187-201. https:// doi.org/10.17512/pjms.2017.16.1.16

31. Silgoner, M., Steiner, K., Wörz, J., \& Schitter, Ch. (2015). Fishing in the Same Pool: Export Strengths and Competitiveness of China and Central. Eastern and Southeastern Europe at the EU-15 Market. China Economic Review, 32, 68-83.

32. Simionescu, M. (2016). Competitiveness and Economic Growth in Romanian Regions. Journal of Competitiveness. 8 (4), 46-60, https://doi.org/10.7441/joc.2016.04.03

33. Smith, K. (2002). What Is the Knowledge Economy? Knowledge Intensity and Distributed Knowledge Bases. UNU/INTECH Discussion Papers, (June), 32. Retrieved (http://eprints. utas.edu.au/1235/).

34. Sopoligová, M., \& Pavelková, D. (2017). Cluster policy in Europe and Asia: A comparison using selected cluster policy characteristics. Journal of International Studies, 10 (3), 35-50. https://doi.org/ 10.14254/2071-8330.2017/10-3/3

35. Suleimenova, G., Sadvokassova, A., Rakisheva, B., \& Nurmaganbetov, A. (2018). Smes development and corruption: case of Kazakhstan. Business: Theory and Practice, 19, 1-8. https://doi.org/10.3846/btp.2018.01

36. Tausch, A. (2010). The European Union's Failed 'Lisbon Strategy. Society and Economy, 32, 103-21.

37. Ungerman, O., Dedkova, J., \& Gurinova, K. (2018). The impact of marketing innovation on the competitiveness of enterprises in the context of industry 4.0. Journal of Competitiveness. 10 (2), 132-148. https://doi.org/10.7441/joc.2018.02.0

38. Ussahawanitchakit P. (2017) Activity-based costing of canned and processed foods businesses in Thailand: effects on organizational development, business competitiveness and corporate success. Business: Theory and Practice, 18, 215-225. https://doi.org/10.3846/ btp. 2017.023

39. Wierzbicka, W. (2018). Information infrastructure as a pillar of the knowledge-based economy - an analysis of regional differentiation in Poland. Equilibrium. Quarterly Journal of Economics and Economic Policy, 13 (1), 123-139. https://doi.org/10.24136/eq.2018.007.

40. Xu, B. (2010). The Sophistication of Exports: Is China Special? China Economic Review, 21(3), 482-93. Retrieved (http://dx.doi.org/10.1016/j.chieco.2010.04.005).

41. Zeira, J. (2011). Innovations. Patent Races and Endogenous Growth. Journal of Economic Growth, 16, 135-56. 
42. Zizlavsky. O. (2016). Innovation performance measurement: research into Czech business practice. Economic Research-Ekonomska Istraživanja, 29 (1), 816-838. https//doi.org/10.1080/ 1331677X.2016.1235983

43. Zygmunt, A. (2017). Innovation activities of Polish firms. Multivariate analysis of the moderate innovator countries. Oeconomia Copernicana, 8 (4), 505-521. https://doi. org/10.24136/oc.v8i4.31

\section{Contact information}

assoc. prof. Jan Dobrovic, PhD.

University of Prešov in Prešov

Faculty of Management

Konštantinova 16, 08001 Prě̃ov

Slovakia

E-mail:jan.dobrovic@unipo.sk

ORCID: 0000-0002-0637-106X

Ing. Peter Gallo, PhD.

University of Prešov in Prešov

Faculty of Management

Konštantínova 16, 08001 Prě̌ov

Slovakia

E-mail:peter.gallo.1@unipo.sk

Prof. Bohuslava Mihalcova, PhD.

University of Economics in Bratislava

Faculty of Business Economics with seat in Kosice

Tajouského 13, 041 30, Košice, Slovakia

E-mail:bohuslava.mihalcova@euke.sk.

Ing. Lenka Stofova, PhD.

University of Economics in Bratislava

Faculty of Business Economics with seat in Kosice

Tajouskébo 13, 041 30, Košice

Slovakia

E-mail:lenka.stofova@euke.sk

Ing. Petra Szaryszova, PhD.

University of Economics in Bratislava

Faculty of Business Economics with seat in Kosice

Tajouského 13, 041 30, Košice

Slovakia

E-mail:petra.szaryszova@euke.sk 